\title{
Dethiosulfatibacter aminovorans gen. nov., sp. nov., a novel thiosulfate-reducing bacterium isolated from coastal marine sediment via sulfate-reducing enrichment with Casamino acids
}

\author{
Correspondence \\ Susumu Takii \\ takii-susumu@c.metro-u.ac.jp
}

\author{
Susumu Takii, ${ }^{1}$ Satoshi Hanada, ${ }^{2}$ Hideyuki Tamaki, ${ }^{2}$ Yutaka Ueno, ${ }^{2}$ \\ Yuji Sekiguchi, ${ }^{2}$ Akihiro lbe $^{3}$ and Katsumi Matsuura ${ }^{1}$
}

\author{
${ }^{1}$ Department of Biological Sciences, Graduate School of Science, Tokyo Metropolitan University, \\ Minamiohsawa 1-1, Hachioji 192-0397, Japan \\ ${ }^{2}$ Research Institute for Biological Resources and Functions, National Institute of Advanced \\ Industrial Science and Technology (AIST), Higashi 1-1-1 Tsukuba Central 6, Tsukuba 305-8566, \\ Japan \\ ${ }^{3}$ Tokyo Metropolitan Institute of Public Health, Hyakunin-cho 3-24-1, Shinjuku-ku, Tokyo \\ 163-0073, Japan
}

A sulfate-reducing enrichment culture originating from coastal marine sediment of the eutrophic Tokyo Bay, Japan, was successfully established with Casamino acids as a substrate. A thiosulfate reducer, strain $\mathrm{C} / \mathrm{G} 2^{\top}$, was isolated from the enrichment culture after further enrichment with glutamate. Cells of strain $\mathrm{C} / \mathrm{G} 2^{\top}$ were non-motile rods $(0.6-0.8 \mu \mathrm{m} \times 2.2-4.8 \mu \mathrm{m})$ and were found singly or in pairs and sometimes in short chains. Spores were not formed. Cells of strain C/G2 ${ }^{\top}$ stained Gram-negatively, despite possessing Gram-positive cell walls. The optimum temperature for growth was $28-30{ }^{\circ} \mathrm{C}$, the optimum $\mathrm{pH}$ was around 7.8 and the optimum salt concentration was 20-30 $\mathrm{g} \mathrm{I}^{-1}$. Lactate, pyruvate, serine, cysteine, threonine, glutamate, histidine, lysine, arginine, Casamino acids, peptone and yeast extract were fermented as single substrates and no sugar was used as a fermentative substrate. A Stickland reaction was observed with some pairs of amino acids. Fumarate, alanine, proline, phenylalanine, tryptophan, glutamine and aspartate were utilized only in the presence of thiosulfate. Strain C/G2 ${ }^{\top}$ fermented glutamate to $\mathrm{H}_{2}, \mathrm{CO}_{2}$, acetate and propionate. Thiosulfate and elemental sulfur were reduced to sulfide. Sulfate, sulfite and nitrate were not utilized as electron acceptors. The growth of strain $\mathrm{C} / \mathrm{G} 2^{\top}$ on Casamino acids or glutamate was enhanced by co-culturing with Desulfovibrio sp. isolated from the original mixed culture enriched with Casamino acids. The DNA $\mathrm{G}+\mathrm{C}$ content of strain $\mathrm{C} / \mathrm{G} 2^{\top}$ was 41.0 mol\%. Phylogenetic analysis based on $16 \mathrm{~S}$ rRNA gene sequences showed that strain $\mathrm{C} / \mathrm{G} 2^{\top}$ formed a distinct cluster with species of the genus Sedimentibacter. The closest relative was Sedimentibacter hydroxybenzoicus (with a gene sequence similarity of $91 \%$ ). On the basis of its phylogenetic and phenotypic properties, strain $\mathrm{C} / \mathrm{G} 2^{\top}$ (=JCM $13356^{\top}=$ NBRC $101112^{\top}=$ DSM $17477^{\top}$ ) is proposed as representing a new genus and novel species, Dethiosulfatibacter aminovorans gen. nov., sp. nov.
In eutrophic coastal seas where algal blooms frequently occur, an abundance of organic matter originates from phytoplankton rich in proteins (Parsons et al., 1961; Hoshi

Abbreviation: SRB, sulfate-reducing bacteria.

The GenBank/EMBL/DDBJ accession number for the 16S rRNA gene sequence of strain $C / G 2^{\top}$ is $A B 218661$.

Phase-contrast and transmission electron micrographs of cells of strain $\mathrm{C} / \mathrm{G}^{\top}$ and tables detailing the metabolic products of the novel strain from amino acids in pure and co-cultures are available with the online version of this paper. et al., 1994) and is deposited on bottom sediments. These sedimentary proteins have been considered to be hydrolysed to amino acids and further decomposed, mainly by fermentative bacteria such as members of the class Clostridia (MacInerney, 1988). Sulfate-reducing bacteria (SRB) that play a major role in the mineralization of organic matter in coastal sediments (Jørgensen, 1982) have been regarded as minor contributors to the decomposition of proteins and amino acids in such sediments (Burdige, 1989, 1991; Parkes et al., 1989; Hansen \& Blackburn, 1995). However, some species of SRB have been reported to use 
several single amino acids, e.g. members of the genera Desulfovibrio (Stams et al., 1985; van der Maarel et al., 1996; Baena et al., 1998), Desulfobacterium (Rees et al., 1998), Desulfobulbus (Sass et al., 2002), Desulfomusa (Finster et al., 2001) and Desulfotomaculam (Stams \& Hansen, 1986). The main substrates of SRB have been recognized as short chain fatty acids, especially acetate, which are produced by fermentative bacteria in marine sediments (Sørensen et al., 1981; Winfrey \& Ward, 1983; Christensen, 1984; Parkes et al., 1989; Fukui et al., 1997).

However, Hansen et al. (1993) suggested the active participation of SRB in amino acid oxidation in incubation experiments with fish food-amended sediment collected below a marine fish farm. In addition, it has been demonstrated previously that the decomposition of amino acids is suppressed by the addition of molybdate (a specific inhibitor of sulfate reduction) to sediment slurry collected in the highly eutrophic area of Tokyo Bay, Japan, where algal blooms have often been observed in warm seasons (Takii, 2003). This finding suggested that SRB have a close connection with the decomposition of amino acids on the eutrophic sea floor.

Furthermore, we have succeeded in establishing a sulfatereducing enrichment culture with Casamino acids using sediment from Tokyo Bay as an inoculating source. Although versatile sulfate-reducers capable of using many amino acids were not found, the following two strains were successfully isolated from the enrichment: a sulfatereducing bacterium, Desulfovibrio sp. strain C/L2, and a thiosulfate-reducing bacterium, strain $\mathrm{C} / \mathrm{G} 2^{\mathrm{T}}$. The latter strain was able to use various amino acids in the presence of thiosulfate or elemental sulfur as an electron acceptor and its growth on amino acids was enhanced by coculturing with Desulfovibrio sp. strain C/L2. The results of a phylogenetic analysis based on $16 \mathrm{~S}$ rRNA gene sequences revealed that strain $\mathrm{C} / \mathrm{G}^{\mathrm{T}}$ was not closely related to any known bacterium and suggested that this novel thiosulfatereducing isolate might represent a new taxon.

The novel isolate, strain $\mathrm{C} / \mathrm{G} 2^{\mathrm{T}}$ originated from anoxic black sediment. The sediment was collected by an Ekmandredge from a site $\left(35^{\circ} 37^{\prime} 19^{\prime \prime} \mathrm{N}, 140^{\circ} 00^{\prime} 2^{\prime \prime} \mathrm{E}\right)$ in the inner part of Tokyo Bay. At this site, the bottom had been dredged to about $10 \mathrm{~m}$ below the natural sea floor to collect sand (water depth about $20 \mathrm{~m}$ ). At the dredged site, bottom water was apt to stagnate and to be deoxygenated in the summer and the rate of sulfate reduction was also higher at this site than found in the nearby natural sea floor (Takii et al., 2002).

The basal medium used for the enrichment and isolation of thiosulfate- and sulfate-reducing strains was a marine, bicarbonate-buffered, sulfide-reduced medium containing $\left(l^{-1}\right): 4 \mathrm{~g} \mathrm{Na}_{2} \mathrm{SO}_{4} ; 0.2 \mathrm{~g} \mathrm{KH}_{2} \mathrm{PO}_{4} ; 0.25 \mathrm{~g} \mathrm{NH}_{4} \mathrm{Cl} ; 20.0 \mathrm{~g}$ $\mathrm{NaCl} ; 3.0 \mathrm{~g} \mathrm{MgCl}_{2} \cdot 6 \mathrm{H}_{2} \mathrm{O} ; 0.5 \mathrm{~g} \mathrm{KCl}$ and $0.15 \mathrm{~g}$ $\mathrm{CaCl}_{2} \cdot 2 \mathrm{H}_{2} \mathrm{O}$. The following were also added to the medium $\left(1^{-1}\right): 1 \mathrm{ml}$ SL10 trace element solution, $1 \mathrm{ml}$ selenite-tungstate solution, $1 \mathrm{ml}$ vitamin mixture solution,
$1 \mathrm{ml}$ vitamin $\mathrm{B}_{12}$ solution, $30 \mathrm{ml} \mathrm{NaHCO}_{3}$ solution and $7.5 \mathrm{ml} \mathrm{Na} 2 \mathrm{~S} .9 \mathrm{H}_{2} \mathrm{O}$ solution (Widdel \& Bak, 1992). Sterile screw-capped glass bottles $(70 \mathrm{ml})$ filled with the basal medium together with Casamino acids $\left(3.5 \mathrm{~g} \mathrm{l}^{-1}\right)$ were inoculated with a fresh sediment sample (approx. $0.5 \mathrm{~g}$ wet wt.) and were incubated at $30{ }^{\circ} \mathrm{C}$. After several transfers of sulfide-positive cultures, the culture was subjected to the agar shake dilution method (Widdel \& Bak, 1992). An isolated colony was transferred into liquid medium in a small screw-capped tube. Purity was investigated by phasecontrast light microscopy. Despite the repeated isolation procedure, the culture obtained contained two types of morphologically distinct cells. This culture was then successively enriched with glutamate $(10 \mathrm{mM})$ as the sole substrate and the enriched cultures were subjected to the most probable number technique using the same medium. The highest dilution growing tubes were used for inoculation by the agar shake dilution method. Strain $\mathrm{C} / \mathrm{G} 2^{\mathrm{T}}$ was isolated and maintained with a medium supplemented with glutamate. The maintenance medium was prepared by modifying the basal medium by the addition of thiosulfate $(20 \mathrm{mM})$ and dithionite (approx. $40 \mathrm{mg} \mathrm{l}^{-1}$ ) instead of sulfate and sulfide, respectively. All liquid media were dispensed into screw-capped tubes that were completely filled to exclude air from the vessels, unless otherwise described.

Cell morphology was examined under a phase-contrast microscope (Optiphot; Nikon). For transmission electron microscopy, a centrifuged cell pellet was fixed with $5 \%$ $(\mathrm{v} / \mathrm{v})$ glutaraldehyde and $1 \%(\mathrm{v} / \mathrm{v})$ osmium tetroxide. Ultra-thin sections of the sample, embedded in epoxy resin, were prepared with a Reichert ultramicrotome. The sections were post-stained with uranyl acetate and lead citrate and examined using a transmission electron microscope (H-7000; Hitachi). Gram staining was performed according to the Hucker method (Doetsch, 1981) and the $\mathrm{KOH}$ test was performed as described by Gregersen (1978).

Duplicate culture tubes were used in all experiments. Growth at various temperatures, $\mathrm{pH}$ values and $\mathrm{NaCl}$ concentrations was studied using the maintenance medium with added glutamate as described above. The $\mathrm{pH}$ was adjusted with $2 \mathrm{M} \mathrm{HCl}$ or $1 \mathrm{M} \mathrm{Na}_{2} \mathrm{CO}_{3}$. In $\mathrm{NaCl}$ tolerance tests, various amounts of $\mathrm{NaCl}\left(0-60 \mathrm{~g} \mathrm{l}^{-1}\right)$ were added. The utilization of electron donors was tested in the maintenance medium and was evaluated by monitoring the growth (determination of the optical density of the culture) for longer than one month and by the production of hydrogen sulfide as detected by cupric reagent (Widdel \& Bak, 1992). Fermentation was tested with the maintenance medium without thiosulfate. Thiosulfate, sulfate, sulfite, elemental sulfur and nitrate were tested as the sole electron acceptor in the maintenance media without thiosulfate.

The optical density of cultures was measured at $610 \mathrm{~nm}$ by inserting the culture tubes into the cuvette holder of a 
photometer (Tokyo Photoelectric Co.). Catalase was detected by pouring $3 \% \mathrm{H}_{2} \mathrm{O}_{2}$ solution onto a cell pellet in a centrifugation tube. Indole production was tested as described by Smibert \& Krieg (1981). The total DNA of the isolate was extracted as described previously (Kamagata \& Mikami, 1991) and digested with P1 nuclease using a GC kit (Yamasa Shoyu Co.). The DNA G $+\mathrm{C}$ content was measured with an HPLC system (model LC-6A; Shimadzu) equipped with a CLC-ODS column $(6 \times 150 \mathrm{~mm})$. For the analysis of end products, a $40 \mathrm{ml}$ sample of maintenance medium in $70 \mathrm{ml}$ serum vials was used. The gas phase of the vial was replaced with nitrogen gas. The optical density of the liquid cultures was measured in a $1 \mathrm{~cm}$ cuvette at $585 \mathrm{~nm}$ with a spectrophotometer (UV-1600; Shimadzu). Sulfide was determined by the method of Cline (1969). After filtration of the culture with $0.22 \mu \mathrm{m}$ Millipore filters, dissolved organic carbon was analysed by a total organic carbon analyser (TOC-500; Shimadzu). Single amino acids present in the culture media were quantified using the cuprizone method (Janssen \& Barea, 1989). Amino acids in the Casamino acids-amended culture were analysed by an amino acid analyser (L8500; Hitachi). Organic acids in the cultures were determined by HPLC as described previously (Purdy et al., 1997) or GC (GC-8A; Shimadzu) equipped with a packed column (FAL-M 10\%, Shincarbon A; Shinwa Chem. Ind. Ltd) and a flame ionized detector. The column and detector temperatures were 140 and $200{ }^{\circ} \mathrm{C}$, respectively. Hydrogen in the gas phase was analysed by GC (GC-14A; Shimadzu) equipped with a Porapack Q (Waters) column and a thermal conductivity detector. Nitrogen was used as the carrier gas for both GCs.

The 16S rRNA gene fragments were amplified by PCR (Hiraishi, 1992) and sequenced directly on a DNA Sequencer (ABI 310; Applied Biosystems) using a BigDye Terminator version 1.1 cycle terminator kit (Applied Biosystems). The 16S rRNA gene sequence obtained was aligned and compared with reference sequences using the ARB program package (http://www.arb-home.de/). The phylogenetic tree was constructed by the neighbour-joining method (Saitou \& Nei, 1987) with the ARB program package. Bootstrap analysis was performed for 1000 replicates (Felsenstein, 1985).

A stable, sulfate-reducing culture isolated from a sediment sample collected in the inner part of Tokyo Bay was successively enriched with Casamino acids after several transfers of sulfide-positive cultures. Strain $\mathrm{C} / \mathrm{G}_{2}{ }^{\mathrm{T}}$ was isolated from the enrichment culture after further enrichment with glutamate and was used for detailed characterization.

Strain C/G2 ${ }^{\mathrm{T}}$ showed a rod-shaped morphology (0.6$0.8 \mu \mathrm{m} \times 2.2-4.8 \mu \mathrm{m}$ (see Supplementary Fig. S1 in IJSEM Online) without motility. The cells occurred as single cells or pairs and short chains were sometimes formed, especially under sub-optimum conditions. Spore formation was never observed under the microscope under any culture conditions. Although the results of Gram staining and the $\mathrm{KOH}$ lysis test were negative, the cell-wall ultrastructure resembled that of Gram-positive bacteria (see Supplementary Fig. S2 with the online version of this paper).

The optimum growth temperature for strain $\mathrm{C} / \mathrm{G} 2^{\mathrm{T}}$ on glutamate and thiosulfate was $28-30{ }^{\circ} \mathrm{C}$. No growth was observed at 10 or $40{ }^{\circ} \mathrm{C}$. Only faint growth occurred at $37^{\circ} \mathrm{C}$ and most cells formed chains under this condition. The strain grew at an initial $\mathrm{pH}$ range of between 5.9 and 8.8 , with an optimum $\mathrm{pH}$ of around 7.8 . Strain $\mathrm{C} / \mathrm{G} 2^{\mathrm{T}}$ was able to grow in media supplemented with $\mathrm{NaCl}$ at concentrations of $8-55 \mathrm{~g} \mathrm{l}^{-1}$ and optimal growth took place at $\mathrm{NaCl}$ concentrations of between 20 and $30 \mathrm{~g}^{-1}$. Some vitamins were required for growth of the novel strain on glutamate and thiosulfate as no growth was observed at the second transfer ( $1 \%$ inoculation size) to the vitaminfree medium. The addition of yeast extract greatly stimulated both the growth rate and cell yield of the novel strain. Strain $\mathrm{C} / \mathrm{G}^{\mathrm{T}}$ showed fermentative growth on various fatty acids $(20 \mathrm{mM})$ and amino acids $(10 \mathrm{mM})$ as a single substrate, e.g., lactate, pyruvate, serine, cysteine, threonine, glutamate, histidine, lysine and arginine. Complex substrates such as Casamino acids $\left(3.5 \mathrm{~g} \mathrm{l}^{-1}\right)$, peptone $\left(5 \mathrm{~g} \mathrm{l}^{-1}\right)$ and yeast extract $\left(1 \mathrm{~g} \mathrm{l}^{-1}\right)$ were also found to be suitable, whereas gelatin was not. Sugars (20 $\mathrm{mM})$ such as glucose, mannose, maltose and sucrose did not support fermentative growth. A Stickland reaction was observed with alanine, leucine or isoleucine as an electron donor and glycine as the electron acceptor, but the strain did not ferment these substrates as a sole substrate. Indole production was positive in the absence of the electron acceptor. The novel strain was able to use thiosulfate $(20 \mathrm{mM})$ and elemental sulfur $\left(1 \mathrm{~g} \mathrm{l}^{-1}\right)$ as an electron acceptor, but not sulfate $(20 \mathrm{mM})$, sulfite $(5 \mathrm{mM})$ or nitrate $(10 \mathrm{mM})$. The addition of thiosulfate enabled strain $\mathrm{C} / \mathrm{G}^{\mathrm{T}}$ to grow on the following unsuitable fermentative substrates: fumarate, alanine, proline, phenylalanine, tryptophan, glutamine and aspartate.

The metabolic products of Casamino acids and several single amino acids generated by strain $\mathrm{C} / \mathrm{G}^{\mathrm{T}}$ were examined with or without thiosulfate (see Supplementary Table S1 in IJSEM Online). The best growth took place in the culture supplemented with thiosulfate and Casamino acids containing 15 amino acids (glutamate, proline, lysine, aspartate, valine, serine, alanine, leucine, threonine, glycine, arginine, isoleucine, phenylalanine, histidine and methionine, in order of molar concentration). More than $96 \%$ of the initial concentration of all amino acids, apart from alanine, in Casamino acids was consumed after 5 days incubation in the presence of thiosulfate. In the absence of thiosulfate, more than $94 \%$ of the initial concentration of only five amino acids (glutamate, lysine, serine, arginine and histidine) was consumed after 10 days incubation. In addition, the final concentration of alanine increased to $141 \%$ of the initial concentration under the latter condition. Thus, the addition of thiosulfate markedly increased the cell yield and growth rate, suggesting that the 
novel strain is capable of thiosulfate respiration. Acetate and propionate were the main end products from Casamino acids and glutamate, either in the presence or absence of thiosulfate. The ratio of acetate to propionate was also not affected by the addition of thiosulfate. The fermentation products from glutamate were similar to those of Caloramator coolhaasii (Plugge et al., 2000). The only main organic product was acetate in the culture on arginine with or without thiosulfate. Acetate, propionate and an unidentified compound (presumably a fatty acid detected by HPLC) were mainly produced from histidine and proline with thiosulfate. Formate was produced from histidine in place of the unidentified compound when the novel strain was cultured without thiosulfate. Acetate and the unidentified compound were detected from cysteine. Hydrogen was produced from all substrates examined in the absence of thiosulfate, but was produced in lesser amounts in the presence of thiosulfate, as also observed in the cultures on glutamate and histidine.

Growth of strain $\mathrm{C} / \mathrm{G} 2^{\mathrm{T}}$ on Casamino acids and glutamate was clearly enhanced by co-culturing with Desulfovibrio sp. strain C/L2 which was isolated from the original mixed culture enriched with Casamino acids (see Supplementary Table S2). All 15 amino acids initially detected were almost completely utilized in the co-culture, while only four (lysine, valine, arginine and histidine) were used by 5 days of incubation by strain $\mathrm{C} / \mathrm{G} 2^{\mathrm{T}}$ alone. In the pure culture of strain C/L2, only serine, alanine, threonine and glycine were used. Although strain C/L2 could not utilize glutamate, the co-culture showed active sulfate reduction in the glutamate medium. Hydrogen was not accumulated in the co-culture with both substrates. These results clearly suggest that the fermentation of strain $\mathrm{C} / \mathrm{G} 2^{\mathrm{T}}$ is enhanced by the consumption of $\mathrm{H}_{2}$ by the Desulfovibrio strain. This syntrophic relationship, known as interspecies $\mathrm{H}_{2}$ transfer, could play an important role in the decomposition of amino acids in sediments in situ, as well as in the enrichment culture (Stams \& Hansen, 1984).
Neither catalase nor desulfoviridin were detected. The $\mathrm{G}+\mathrm{C}$ content of the genomic DNA of the novel strain was $41.0 \mathrm{~mol} \%$.

Phylogenetic analysis of a nearly full length $16 \mathrm{~S}$ rRNA gene sequence $(1479 \mathrm{bp})$ from strain $\mathrm{C} / \mathrm{G}^{\mathrm{T}}{ }^{\mathrm{T}}$ showed that the novel strain belongs to the order Clostridiales of the phylum Firmicutes, but exhibits less than $92 \%$ sequence similarity with any known cultured bacteria (Fig. 1). The closest relatives of strain $\mathrm{C} / \mathrm{G}^{\mathrm{T}}$ were Sedimentibacter hydroxybenzoicus (gene sequence similarity of $91 \%)$, Clostridium acidurici (90\%), Sedimentibacter saalensis (91\%), Soehngenia saccharolytica (92\%), Sporanaerobacter acetigenes (92\%), Clostridium purinilyticum (91\%) and Eubacterium angustum (91\%). The novel strain formed a distinct cluster with members of the genus Sedimentibacter (Breitenstein et al., 2002) with a high bootstrap value $(>95 \%)$, but was far distant from the clostridial clusters XI, XII and XIII (Collins et al., 1994).

Table 1 shows the differential characteristics between strain $\mathrm{C} / \mathrm{G} 2^{\mathrm{T}}$ and closely related species. Like strain $\mathrm{C} / \mathrm{G}^{\mathrm{T}}{ }^{\mathrm{T}}$, Sedimentibacter hydroxybenzoicus and Sedimentibacter saalensis could ferment several amino acids but could not use gelatin or sugars. Furthermore, Sedimentibacter saalensis reduced thiosulfate and fermented pyruvate. These features were quite similar to those of strain $\mathrm{C} / \mathrm{G} 2^{\mathrm{T}}$. However, these Sedimentibacter species were spore-forming curved rods isolated from freshwater environments and did not produce $\mathrm{H}_{2}$, whereas strain $\mathrm{C} / \mathrm{G}^{\mathrm{T}}$ was a rod-shaped marine bacterium showing no sporulation, but producing $\mathrm{H}_{2}$. Another species of the genus Sedimentibacter, 'Sedimentibacter hongkongensis', the physiological characteristics of which have not yet been described in detail, was isolated from a blood culture of a patient (Woo et al., 2004). Recently, many thiosulfate- and/or sulfur-reducing bacteria belonging to the order Clostridiales have been found and described. These include the thiosulfatereducing Alkaliphilus transvaalensis (Takai et al., 2001) and Fusibacter paucivorans (Ravot et al., 1999) in clostridial

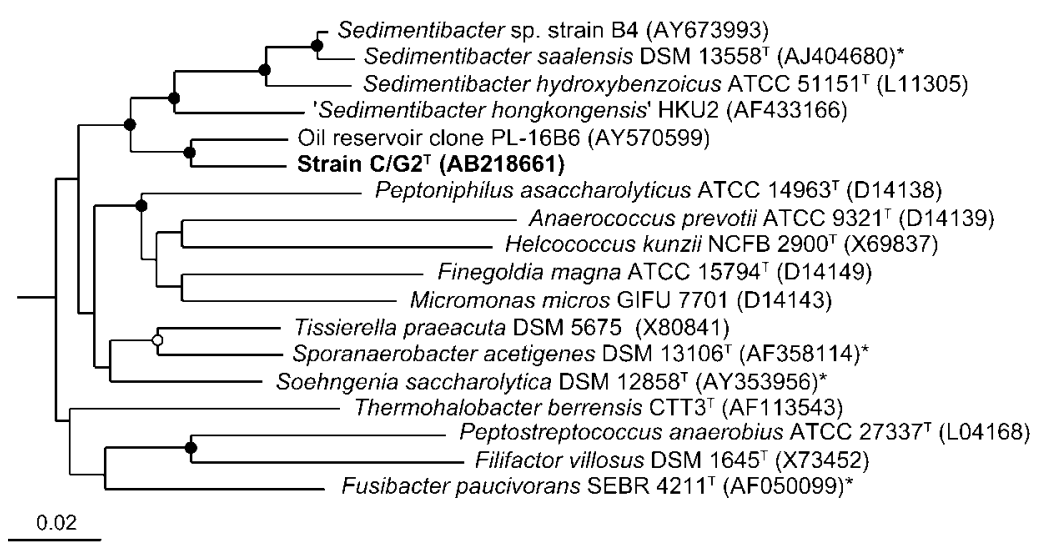

XIII

XII

XI

0.02
Fig. 1. Phylogenetic tree indicating the position of strain $\mathrm{C} / \mathrm{G} 2^{\top}$ among representatives of cluster XI, XII, and XIII of the clostridia (Collins et al., 1994). The tree is based on a distance matrix of 16S rRNA gene sequences and was constructed using the neighbour-joining method. Thermoanaerobacterium saccharolyticum DSM $7060^{\top}$ (GenBank accession number L09169) was used as an outgroup (not shown). Asterisks indicate bacteria able to use thiosulfate and/or elemental sulfur as an electron acceptor. Filled circles at nodes indicate branches with a bootstrap value of $>95 \%$; open circles at nodes indicate branches with a bootstrap value of $>80 \%$. Bar, $2 \%$ sequence divergence. 
Table 1. Characteristics used for distinguishing strain $\mathrm{C} / \mathrm{G} 2^{\top}$ from related species

Taxa: 1, strain C/G2 ${ }^{\mathrm{T}}$ (data from this study); 2, Sedimentibacter hydroxybenzoicus (Zhang et al., 1994); 3, Sedimentibacter saalensis (Breitenstein et al., 2002); 4, 'Sedimentibacter hongkongensis' (Woo et al., 2004). +, Positive or used; -, negative or not used; ( +), used only by Stickland reaction; ND, not described. The following characteristics tested negative for all strains: sulfate reduction (except taxa 3 and 4, ND), nitrate reduction, fermentation of carbohydrates and gelatin hydrolysis (except taxon 4, ND). All strains utilize lysine except for taxon 4 (ND).

\begin{tabular}{|c|c|c|c|c|}
\hline Characteristic & 1 & 2 & 3 & 4 \\
\hline Cell morphology & Straight rod & Slightly curved rod & Slightly curved rod & Straight or slightly curved rod \\
\hline Gram stain & - & - & + & - \\
\hline Spore formation & - & + & + & + \\
\hline Motility & - & - & + & + \\
\hline Temperature range for growth $\left({ }^{\circ} \mathrm{C}\right)$ & $15-37$ & $12-41$ & $14-40$ & ND \\
\hline Optimum temperature for growth $\left({ }^{\circ} \mathrm{C}\right)$ & $28-30$ & $33-34$ & 37 & ND \\
\hline $\mathrm{pH}$ range for growth & $5.9-8.8$ & $6.1-10$ & $5.8-8.0$ & $\mathrm{ND}$ \\
\hline Optimum $\mathrm{pH}$ for growth & 7.8 & $7.2-8.2$ & $6.8-7.3$ & $\mathrm{ND}$ \\
\hline DNA G $+C$ content $(\mathrm{mol} \%)$ & 41.0 & 35.5 & 34 & ND \\
\hline Catalase production & - & - & - & + \\
\hline Indole production & + & + & - & + \\
\hline $\mathrm{H}_{2}$ production & + & - & - & ND \\
\hline Thiosulfate reduction & + & - & + & $\mathrm{ND}$ \\
\hline \multicolumn{5}{|l|}{ Substrates utilized: } \\
\hline Lactate & + & - & ND & ND \\
\hline Pyruvate & + & - & + & ND \\
\hline Glycine & - & + & + & ND \\
\hline Arginine & + & $(+)$ & $(+)$ & $\mathrm{ND}$ \\
\hline Source & Marine sediment & Freshwater sediment & Freshwater sediment & Human clinical specimen \\
\hline
\end{tabular}

cluster XI, thiosulfate-reducing Soehngenia saccharolytica (Parshina et al., 2003) and sulfur-reducing Sporanaerobacter acetigenes (Hernández-Eugenio et al., 2002a) in cluster XII and Clostridium thiosulfatireducens (HernándezEugenio et al., 2002b) and Clostridium peptidivorans (Mechichi et al., 2000) in cluster I. All these thiosulfateand/or sulfur-reducing species of the order Clostridiales belong to clostridial clusters I, XI or XII and are phylogenetically distant from strain $\mathrm{C} / \mathrm{G} 2^{\mathrm{T}}$. In addition, in contrast to strain $\mathrm{C} / \mathrm{G} 2^{\mathrm{T}}$, spore formation has been observed in all these species except for Fusibacter paucivorans and they also showed clear differences from strain $\mathrm{C} / \mathrm{G} 2^{\mathrm{T}}$ in the following characteristics: fermentation of sugars (Fusibacter paucivorans, Soehngenia saccharolytica and Sporanaerobacter acetigenes) and hydrolysis of gelatin (Clostridium thiosulfatireducens and Clostridium peptidivorans). Strain $\mathrm{C} / \mathrm{G} 2^{\mathrm{T}}$, on the other hand, phenotypically resembled the thiosulfate-reducing bacteria Dethiosulfovibrio peptidovorans (Magot et al., 1997), Dethiosulfovibrio russensis, Dethiosulfovibrio marinus and Dethiosulfovibrio acidaminovorans (Surkov et al., 2001) that belong to the other family in this order, the family Syntrophomonadaceae. These species are slightly halophilic, non-sporulating and utilize five to eleven amino acids, including glutamate, as a single substrate in the presence of thiosulfate as an electron acceptor, but are unable to use sugars. In spite of the phenotypic similarities, these species of the genus Dethiosulfovibrio were far distant from strain $\mathrm{C} / \mathrm{G} 2^{\mathrm{T}}$ when analysed phylogenetically. On the basis of its phylogenetic and phenotypic properties, we propose to assign strain $\mathrm{C} / \mathrm{G} 2^{\mathrm{T}}$ as representing a novel species of a new genus in the order Clostridiales, with the name Dethiosulfatibacter aminovorans gen. nov., sp. nov.

\section{Description of Dethiosulfatibacter gen. nov.}

Dethiosulfatibacter (De.thio.sul.fa.ti.bac.ter. L. pref. de from; N.L. n. thiosulfas -atis thiosulfate; N.L. masc. n. bacter a rod or staff; N.L. masc. n. Dethiosulfatibacter a rodshaped thiosulfate-reducer).

Rod-shaped cells, singly or in pairs and sometimes forming short chains. Gram stain is negative, non-motile, no spore formation. Strictly anaerobic, mesophilic, neutrophilic and halophilic. Thiosulfate and elemental sulfur can serve as terminal electron acceptors, but sulfate, sulfite and nitrate are not reduced. Amino acids and some organic acids are incompletely oxidized by thiosulfate or sulfur reduction and are fermented to short chain fatty acids such as acetate and propionate. The genus Dethiosulfatibacter belongs to the order Clostridiales in the phylum Firmicutes. The type species is Dethiosulfatibacter aminovorans.

\section{Description of Dethiosulfatibacter aminovorans sp. nov.}

Dethiosulfatibacter aminovorans (a.mi.no.vo'rans. N.L. neut. n. aminum amine; L. part. adj. vorans devouring; N.L. part. adj. aminovorans devouring amino acids). 
Cells with Gram-positive cell wall but stain Gramnegatively. Cells are non-motile, rod-shaped (0.6$0.8 \mu \mathrm{m} \times 2.2-4.8 \mu \mathrm{m}$ ), occur singly or in pairs and sometimes in short chains with no spore formation. Exhibits anaerobic growth by thiosulfate or sulfur reduction or fermentation. Lactate, pyruvate, serine, cysteine, threonine, glutamate, histidine, lysine, arginine, Casamino acids, peptone and yeast extract are fermented. Fumarate, alanine, proline, phenylalanine, tryptophan, glutamine and aspartate are utilized only in the presence of thiosulfate. Acetate, propionate and other short chain fatty acids are produced as the result of fermentation or incomplete oxidation. Acetate, propionate, butyrate, malate, succinate, ethanol, glycine, valine, leucine, isoleucine, methionine, tyrosine, asparagine, gelatin and sugars (glucose, mannose, maltose and sucrose) are not utilized. Vitamins are required for the growth on glutamate and thiosulfate. Yeast extract greatly stimulates growth. Mesophilic, neutrophilic organism isolated from a marine environment. Optimum growth takes place at a $\mathrm{pH}$ of around 7.8 , temperature of $28-30{ }^{\circ} \mathrm{C}$ and salt concentration of 20 $30 \mathrm{~g} \mathrm{l}^{-1}$. Desulfoviridin and catalase are absent. Indole production is positive. The $\mathrm{G}+\mathrm{C}$ content of genomic DNA is $41.0 \mathrm{~mol} \%$.

The type strain, $\mathrm{C} / \mathrm{G} 2^{\mathrm{T}} \quad\left(=\mathrm{JCM} \quad 13356^{\mathrm{T}}=\mathrm{NBRC}\right.$ $101112^{\mathrm{T}}=$ DSM $17477^{\mathrm{T}}$ ), was isolated from an enrichment culture with Casamino acids that was inoculated with anoxic sediment from a highly eutrophic area of Tokyo Bay, Japan.

\section{Acknowledgements}

The authors wish to acknowledge Hideyuki Tanaka, Kunio Kohata, Yasuo Nakamura, Hisako Ogura, and Shunji Takeshita together with the crew of V Kiyosumi of the Department of Environment, Chiba Prefectural Government, for their valuable help during sampling. This study was supported in part by a grant from the Japanese Ministry of Education, Culture, Sports, Science and Technology and the Fund for Special Research Projects at Tokyo Metropolitan University.

\section{References}

Baena, S., Fardesu, M.-L., Labat, M., Ollivier, B., Garcia, J.-L. \& Patel, B. K. C. (1998). Desulfovibrio aminophilus sp. nov., a novel amino acid degrading and sulfate reducing bacterium from an anaerobic dairy wastewater lagoon. Syst Appl Microbiol 21, 498-504.

Breitenstein, A., Wiegel, J., Haertig, C., Weiss, N., Andeesen, J. R. \& Lechner, U. (2002). Reclassification of Clostridium hydroxybenzoicum as Sedimentibacter hydroxybenzoicus gen. nov., comb. nov., and description of Sedimentibacter saalensis sp. nov. Int J Syst Evol Microbiol 52, 801-807.

Burdige, D. (1989). The effects of sediment slurrying on microbial processes, and the role of amino acids as substrates for sulfate reduction in anoxic marine sediments. Biogeochemistry 8, 1-23.

Burdige, D. J. (1991). Microbial processes affecting alanine and glutamic acid in anoxic marine sediments. FEMS Microbiol Lett 85, 211-232.

Christensen, D. (1984). Determination of substrates oxidized by sulfate reduction in intact cores of marine sediments. Limnol Oceanogr 29, 189-192.
Cline, J. D. (1969). Spectrophotometric determination of hydrogen sulfide in natural waters. Limnol Oceanogr 14, 454-458.

Collins, M. D., Lawson, P. A., Willems, A., Cordoba, J. J., FernandezGarayzabal, J., Garcia, P., Cai, J., Hippe, H. \& Farrow, J. A. E. (1994). The phylogeny of the genus Clostridium: proposal of five new genera and eleven new species combinations. Int J Syst Bacteriol 44, 812-826.

Doetsch, R. N. (1981). Determinative methods of light microscopy. In Manual of Methods for General Bacteriology, pp. 21-33. Edited by P. Gerhardt, R. G. E. Murray, R. N. Costilow, E. W. Nester, W. A. Wood, N. R. Krieg \& G. B. Phillips. Washington, DC: American Society of Microbiology.

Felsenstein, J. (1985). Confidence limits on phylogenies: an approach using the bootstrap. Evolution 39, 783-791.

Finster, K., Thomsen, T. R. \& Ramsing, N. B. (2001). Desulfomusa hansenii gen. nov., sp. nov., a novel marine propionate-degrading, sulfate-reducing bacterium isolated from Zostera marina root. Int $J$ Syst Evol Microbiol 51, 2055-2061.

Fukui, M., Suh, J., Yonezawa, Y. \& Urushigawa, Y. (1997). Major substrates for microbial sulfate reduction in the sediments of Ise Bay, Japan. Ecol Res 12, 201-209.

Gregersen, T. (1978). Rapid method for distinction of Gram-negative from Gram-positive bacteria. Eur J Appl Microbiol Biotechnol 5, 123-127.

Hansen, L. S. \& Blackburn, T. H. (1995). Amino acid degradation by sulfate-reducing bacteria: evaluation of four methods. Limnol Oceanogr 40, 502-510.

Hansen, L. S., Holmer, M. \& Blackburn, T. H. (1993). Mineralization of organic nitrogen and carbon (fish food) added to anoxic sediment microcosms: role of sulphate reduction. Mar Ecol Prog Ser 102, 199-204.

Hernández-Eugenio, G., Fardeau, M.-L., Cayol, J.-L., Patel, B. K. C., Thomas, P., Macarie, H., Garcia, J.-L. \& Ollivier, B. (2002a). Sporanaerobacter acetigenes gen. nov., sp. nov., a novel acetigenic, facultatively sulfur-reducing bacterium. Int J Syst Evol Microbiol 52, 1217-1223.

Hernández-Eugenio, G., Fardeau, M.-L., Cayol, J.-L., Patel, B. K. C., Macarie, H., Garcia, J.-L. \& Ollivier, B. (2002b). Clostridium thiosulfatireducens sp. nov., a proteolytic, thiosulfate- and sulfurreducing bacterium isolated from an upflow anaerobic sludge blanket (USAB) reactor. Int J Syst Evol Microbiol 52, 1461-1468.

Hiraishi, A. (1992). Direct automated sequencing of $16 \mathrm{~S}$ rDNA amplified by polymerase chain reaction from bacterial cultures without DNA purification. Lett Appl Microbiol 15, 210-213.

Hoshi, J., Ogawa, H. \& Ogura, N. (1994). The amino acid distribution and behavior of different particle sizes in surface waters of the estuarine and inner part of Tokyo Bay. Chikyukagaku (Geochemistry) 28, 1-14 (in Japanese with English summary).

Janssen, P. H. \& Barea, H. (1989). Rapid determination of amino acid concentrations in microbiological media: evaluation of Borchers' cuprizone method. J Microbiol Methods 10, 311-316.

Jørgensen, B. B. (1982). Mineralization of organic matter in the sea bed - the role of sulphate reduction. Nature 296, 643-645.

Kamagata, Y. \& Mikami, E. (1991). Isolation and characterization of a novel thermophilic Methanosaeta strain. Int J Syst Bacteriol 41, 191-196.

Maclnerney, M. J. (1988). Anaerobic hydrolysis and fermentation of fats and proteins. In Biology of Anaerobic Microorganisms, pp. 373415. Edited by A. J. B. Zehnder. New York: John Wiley \& Sons.

Magot, M., Ravot, G., Campaignolle, X., Ollivier, B., Patel, B. K. C., Fardeau, M.-L., Thomas, P., Crolet, J.-L. \& Garcia, J.-L. (1997). Dethiosulfovibrio peptidovorans gen. nov., sp. nov., a new anaerobic, 
slightly halophilic, thiosulfate-reducing bacterium from corroding offshore oil wells. Int J Syst Bacteriol 47, 818-824.

Mechichi, T., Fardeau, M.-L., Labat, M., Garcia, J.-L., Verhé, F. \& Patel, B. K. C. (2000). Clostridium peptidivorans sp. nov., a peptidefermenting bacterium from an olive mill wastewater treating digester. Int J Syst Evol Microbiol 50, 1259-1264.

Parkes, R. J., Gibson, G. R., Mueller-Harvey, I., Buckingham, W. J. \& Herbert, R. J. (1989). Determination of the substrates for sulphatereducing bacteria within marine and estuarine sediments with different rates of sulphate reduction. J Gen Microbiol 135, 175-187.

Parshina, S. N., Kleerebezem, R., Sanz, J. L., Lettinga, G., Nozhevnikova, A. N., Kostrikina, N. A., Lysenko, A. M. \& Stams, A. J. M. (2003). Soehngenia saccharolytica gen. nov., sp. nov. and Clostridium amygdalinum sp. nov., two novel anaerobic, benzaldehyde-converting bacteria. Int J Syst Evol Microbiol 53, 1791-1799.

Parsons, T. R., Stephens, K. \& Strickland, J. D. H. (1961). On the chemical composition of eleven species of marine phytoplankters. J Fish Res Board Can 18, 1001-1016.

Plugge, C. M., Zoetendal, E. G. \& Stams, A. J. M. (2000). Caloramator coolhaasii sp. nov., a glutamate-degrading, moderately thermophilic anaerobe. Int J Syst Evol Microbiol 50, 1155-1162.

Purdy, K. J., Nedwell, D. B., Embley, T. M. \& Takii, S. (1997). Use of $16 \mathrm{~S}$ rRNA-targeted oligonucleotide probes to investigate the occurrence and selection of sulfate-reducing bacteria in response to nutrient addition to sediment slurry microcosms from a Japanese estuary. FEMS Microbiol Ecol 24, 221-234.

Ravot, G., Magot, M., Fardeau, M.-L., Patel, B. K. C., Thomas, P., Garcia, J.-L. \& Ollivier, B. (1999). Fusibacter paucivorans gen. nov., sp. nov., an anaerobic, thiosulfate-reducing bacterium from an oilproducing well. Int J Syst Bacteriol 49, 1141-1147.

Rees, G. N., Harfoot, C. G. \& Sheehy, A. J. (1998). Amino acid degradation by the mesophilic sulfate-reducing bacterium Desulfobacterium vacuolatum. Arch Microbiol 169, 76-80.

Saitou, N. \& Nei, M. (1987). The neighbor joining method: a new method for reconstructing phylogenetic trees. Mol Biol Evol 4, 406-425.

Sass, A., Rutters, H., Cypionka, H. \& Sass, H. (2002). Desulfobulbus mediterraneus sp. nov., a sulfate-reducing bacterium growing on mono- and disaccharides. Arch Microbiol 177, 468-474.

Smibert, R. M. \& Krieg, N. R. (1981). General characterization. In Manual of Methods for General Bacteriology, pp. 409-443. Edited by P. Gerhardt, R. G. E. Murray, R. N. Costilow, E. W. Nester, W. A. Wood, N. R. Krieg \& G. B. Phillips. Washington, DC: American Society of Microbiology.

Sørensen, J., Christensen, D. \& Jørgensen, B. B. (1981). Volatile fatty acids and hydrogen as substrates for sulfate-reducing bacteria in anaerobic marine sediment. Appl Environ Microbiol 42, 5-11.
Stams, A. J. M. \& Hansen, T. A. (1984). Fermentation of glutamate and other compounds by Acidaminobacter hydrogenoformans gen. nov., sp. nov., an obligate anaerobe isolated from black mud. Studies with pure cultures and mixed cultures with sulfate-reducing and methanogenic bacteria. Arch Microbiol 137, 329-337.

Stams, A. J. M. \& Hansen, T. A. (1986). Metabolism of L-alanine in Desulfotomaculum ruminis and two marine Desulfovibrio strains. Arch Microbiol 145, 277-279.

Stams, A. J. M., Hansen, T. A. \& Skyring, G. W. (1985). Utilization of amino acids as energy substrates by two marine Desulfovibrio strains. FEMS Microbiol Ecol 31, 11-15.

Surkov, A. V., Dubinina, G. A., Lysenko, A. M., Glöckner, F. O. \& Kuever, J. (2001). Dethiosulfovibrio russensis sp. nov., Dethiosulfovibrio marinus sp. nov. and Dethiosulfovibrio acidaminovorans sp. nov., novel anaerobic, thiosulfate- and sulfur-reducing bacteria isolated from 'Thiodendron' sulfur mats in different saline environments. Int $J$ Syst Evol Microbiol 51, 327-337.

Takai, K., Moser, D. P., Onstott, T. C., Spoelstra, N., Pfiffner, S. M., Dohnalkova, A. \& Fredrickson, J. K. (2001). Alkaliphilus transvaalensis gen. nov., sp. nov., an extremely alkaliphilic bacterium isolated from a deep South African gold mine. Int J Syst Evol Microbiol 51, 1245-1256.

Takii, S. (2003). Amino acids as main substrates for sulfate-reducing bacteria in surface sediment of a eutrophic bay. J Gen Appl Microbiol 49, 329-336.

Takii, S., Tanaka, H., Kohata, K., Nakamura, Y., Ogura, H. \& Takeshita, S. (2002). Seasonal changes in sulfate reduction in sediments in the inner part of Tokyo Bay. Microbes Environ 17, 10-17. van der Maarel, M. J. E. C., van Bergeijk, S., van Werkhoven, A. F., Laverman, A. M., Meijer, W. G., Stam, W. T. \& Hansen, T. A. (1996). Cleavage of dimethylsulfoniopropionate and reduction of acrylate by Desulfovibrio acrylicus sp. nov. Arch Microbiol 166, 109-115.

Widdel, F. \& Bak, F. (1992). Gram-negative mesotrophic sulfatereducing bacteria. In The Prokaryotes, 2nd edn, vol. 4, pp. 3352-3378. Edited by A. Balows, H. G. Trüper, M. Dworkin, W. Harder \& K.-H. Schleifer. New York: Springer-Verlag.

Winfrey, M. R. \& Ward, D. M. (1983). Substrates for sulfate reduction and methane production in intertidal sediments. Appl Environ Microbiol 45, 193-199.

Woo, P. C. Y., Teng, J. L. L., Leung, K.-w., Lau, S. K. P., Wong, M. K. M. \& Yuen, K.-y. (2004). Bacteremia in a patient with colonic carcinoma caused by a novel Sedimentibacter hongkongensis sp. nov. Diagn Microbiol Infect Dis 50, 81-87.

Zhang, X., Mandelco, L. \& Wiegel, J. (1994). Clostridium hydroxybenzoicum sp. nov., an amino acid-utilizing, hydroxybenzoatedecarboxylating bacterium isolated from methanogenic freshwater pond sediment. Int J Syst Bacteriol 44, 214-222. 